\title{
EXTENT AND FREQUENCY OF FLOODS \\ ON THE SCHUYLKILL RIVER NEAR \\ PHOENIXVILLE AND POTTSTOWN, PENNSYLVANIA
}

\section{By}

William F. Busch

Lewis C. Shaw 


\section{EXTENT AND FREQUENCY OF FLOODS \\ ON THE SCHUYLKILL RIVER NEAR \\ PHOENIXVILLE AND POTTSTOWN, PENNSYLVANIA}

\section{By}

William F. Busch

Lewis C. Shaw 


\section{PREFACE}

This report covering the extent and frequency of inundation on the Schuylkill River in the vicinity of Phoenixville and Pottstown was prepared as part of a cooperative program between the U.S. Geological Survey and the Delaware River Basin Commission.

Similar flood-inundation studies and reports concerning the Delaware River basin are in progress or have been completed. Specific information as to location and status of these studies can be obtained from the following:

Delaware River Basin Commission

25 Scotch Road

P.O. Box 360

Trenton, N.J. 08603

U.S. Geological Survey

P.O. Box 1238

Trenton, N.J. 08607

U.S. Geological Survey

P.O. Box 1107

Harrisburg, Pa. 17108 
Streamflow data for the Schuylkill River are probably as abundant as those for any stream in the state. Records of peak gage heights and discharge on the Schuylkill River at Reading extend back to 1757 . From 1757 to 1894,19 floods were recorded. A record of annual flood peaks since 1928 is available for the Schuylkill River at Pottstown. A continuous record is also available for Philadelphia from 1932 to the present.

The early records through 1931 were collected by the Pennsylvania Department of Forests and Waters and its predecessor, the Water Supply Commission of Pennsylvania. After 1931 the records were collected under a cooperative agreement between the Geological Survey and the Pennsylvania Department of Forests and waters and its successor, the Office of Engineering and Construction of the Pennsylvania Department of Environmental Resources. Data on high-water marks and areas inundated during flooding have been obtained from many local residents, plant officials, and other government agencies. 
Page

Preface - -

Introduction 1

Description of the area 3

The river 6

The flood plain 7

Method of analysis 8

Data available $-1-08$

Gage records

Map - - 12

Field investigation 12

Magnitude and frequency of floods - 14

Modification of flood elevations due to major

flood-control structures 16

Flood profiles - 17

Use of frequency and profile relations 19

Areal extent of flooding 20

Depth of flooding 21

Cross sections - 21

Limitations of data 28

Selected bibliography -29 


\section{ILLUSTRATIONS}

Page

Plate 1.--Topographic map of Schuylkill River in

vicinity of Phoenixville and

Pottstown, Pa.

In Pocket

Figure 1.--Elevations of annual maximum flood

peaks on the Schuylkill River

at Pottstown, $\mathrm{Pa}$

10

2.--Frequency of floods on the Schuylkill

River at Pottstown, Pa

11

3.--Flood profiles on the Schuylkill River-

4-9.--Cross sections on the Schuylkill River:

4.--At mile 53.7

5.--At mile 46.84

6.--At mile 44.7

7.--At mile 42.05

25

8.--At mile 38.05

9.--At mile 35.75 


\section{TABLES}

Page

Table 1.--Flood-crest and low-water elevations on

the Schuylkill River --- - -

2.--Annual maximum flood peaks on Schuylkill

River at Pottstown, Pa.

3.--Mean sea level reference marks - 
EXTENT AND FREQUENCY OF FLOODS

ON THE SCHUYLKILL RIVER NEAR

PHOENIXVILLE AND POTTSTOWN, PENNSYLVANIA

By

William F. Busch and Lewis C. Shaw

INTRODUCTION

Knowledge of the frequency and extent of flooding is an important requirement for the design of all works of man bordering or encroaching on flood plains. The proper design of bridges, culverts, dams, highways, levees, reservoirs, sewage-disposal systems, waterworks and all structures on the flood plains of streams requires careful consideration of flood hazards. 
By use of relations presented in this report, the extent, depth, and frequency of flooding can be estimated for any site along the reach of the Schuylkill River from Oaks to Pottstown. These flood data are presented so that regulatory agencies, organizations, and individuals may have a technical basis for making decisions on the use of flood-prone areas. The Delaware River Basin Commission and the U. S. Geological Survey regard this program of flood-plain-inundation studies as a positive step toward flood-damage prevention. Flood-plaininundation studies are a prerequisite to flood-plain management which may include a mixture of flood-control structures and/or land-use regulations. Both physical works and flood-plain regulations are included in the Comprehensive Plan for development of the Delaware River basin, of which the Schuylkill River is a part.

Recommendations for land use, or suggestions for limitations of land use, are not made herein. Other reports on use and regulation of land in flood-prone areas are available (Dola, 1961; White, 1961; American Society of Civil Engineers Task Force on Flood Plain Regulations, 1962; and Goddard, 1963). The primary responsibility for planning for optimum land use in the flood plain and the implementation of flood-plain zoning or other regulations to achieve such optimum use rests with state, and local interests. 


\section{Description of the Area}

The area described in this report consists of the Schuylkill River and its flood plain from a short distance about the mouth of Perkiomen Creek near Oaks (lat 40\%07'30", mile 32.7) to gaging station 01472000 on the Hanover Street Bridge in Pottstown (mile 53.7) a distance of 21.0 river miles, as shown on plate 1 . All river miles used in the report are miles upstream from the mouth of the Schuylkill River, as computed by the Delaware River Basin Commission (table 1).

The Schuylkill River is the boundary between Montgomery and Chester Counties, Montgomery County being on the left bank.

Tributaries to the Schuylkill River within the reach of this study, in their downstream order, with drainage area in parentheses, are: Sprogles Run (7.06 sq mi), Sanatoga Creek (7.09 sq mi), Possum Hollow Run (1.40 sq mi), Brook Evans Creek (1.53 sq mi), Pigeon Creek (14.5 sq mi), Mingo Creek (7.92 sq mi), Stony Run (5.62 sq mi), French Creek (70.2 sq $\mathrm{mi})$, and Pickering Creek (38.8 sq $\mathrm{mi})$. 


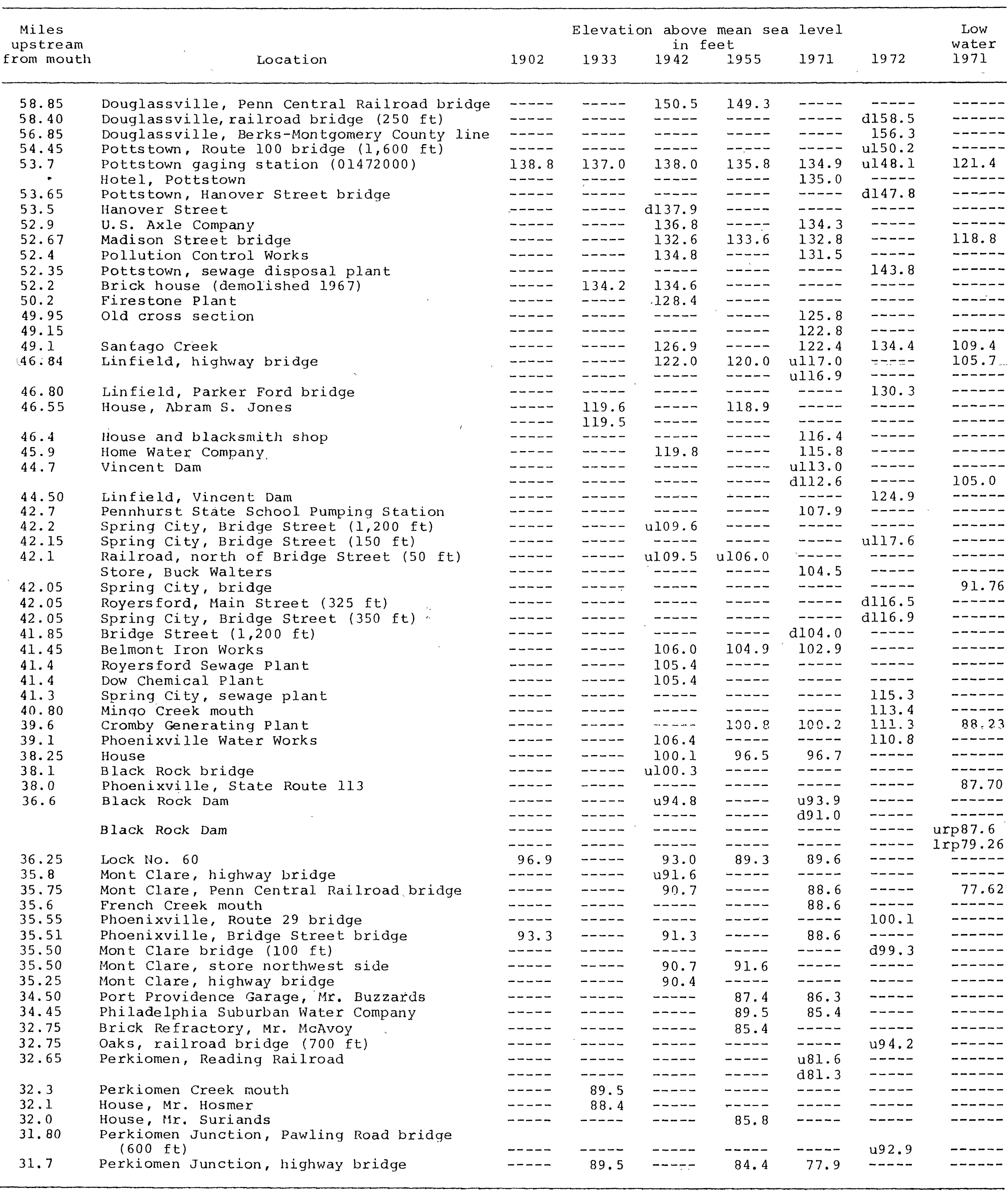

$u$, upstream

d, downstream.

urp, upper reference point.

Irp, lower reference point. 
Flooding on the tributaries is not shown, except for short distances above their mouths where they are affected by backwater from the Schuylkill River.

Four cities border on the Schuylkill River in the reach under study - Pottstown, Royersford, Spring City, and Phoenixville. Eight highway and six railroad bridges cross the stream in the study section.

The drainage area is 1,147 square miles at the upper limit of the study area and 1,328 square miles above Perkiomen Creek. 
The River

The Schuylkill River, a tributary of the Delaware River, rises at Tuscarora Springs in Schuylkill County and flows south and east approximately 130 miles to the Delaware River. There are two pools above dams on the river in the study area. The one above Black Rock Dam is $2.9 \mathrm{miles}$ long and has an area of 95 acres; the one above Vincent Dam is 2.1 miles long and has an area of approximately 70 acres. These dams and pools were a part of the Schuylkill River canal system, which was in operation from 1824 to 1917 . When the canal was in operation, there were many additional dams, which have since been breached. They were connected by a system of canals and locks along the river. The two dams mentioned above have the following characteristics: Black Rock Dam - drainage area above dam, 1,296 sq mi; height, Il ft; spillway elevation, $85.9 \mathrm{ft}$; length, $370 \mathrm{ft}$. Vincent Dam - drainage area above dam, 1,150 sq mi; height, 12 ft; spillway crest elevation, $103.5 \mathrm{ft}$; length, $350 \mathrm{ft}$. The segment of the river studied has an average fall of 2.5 feet per mile. 


\section{The Flood Plain}

The channel of the Schuylkill River in the study reach is flanked in most places by either natural high banks or railroad embankments; consequently, the flood plain is narrow in most places. At low and median stages there is little flooding, but at high stages there is extensive flooding at Pottstown and South Pottstown. 
METHOD OF ANALYSIS

The method of analysis used in preparing this report conforms to "Phase I" method described by Wiitala, Jetter, and Somerville (1961).

\section{Data Available}

Data previously published by the Geological Survey and other Federal agencies plus data obtained in the field have been used in this report.

\section{Gage Records}

Continuous gage-height records have been collected at a gaging station on the Schuylkill River at Pottstown from October 1927 to the present time (1973). This gage is at mile 53.7, the upstream end of the study reach. The drainage area is 1,147 square miles. Datum of gage is 117.86 feet above mean sea level, datum of 1929 .

The annual maximum flood peaks of the period of record are listed in Table 2 and shown in figure 1. The highest known peak (Feb. 28, 1902) before June 23, 1972, is listed and was used in developing the frequency curve (fig. 2). The peak of record (June 23, 1972) is also listed, but was not used in developing the frequency curve. 
Table 2.-- Annual maximum flood peaks on Schuylkill River at Pottstown, Pa. [Drainage area is $1,147 \mathrm{sq} \mathrm{mi}$; datum of gage is $117.86 \mathrm{ft}$ above mean sea level]

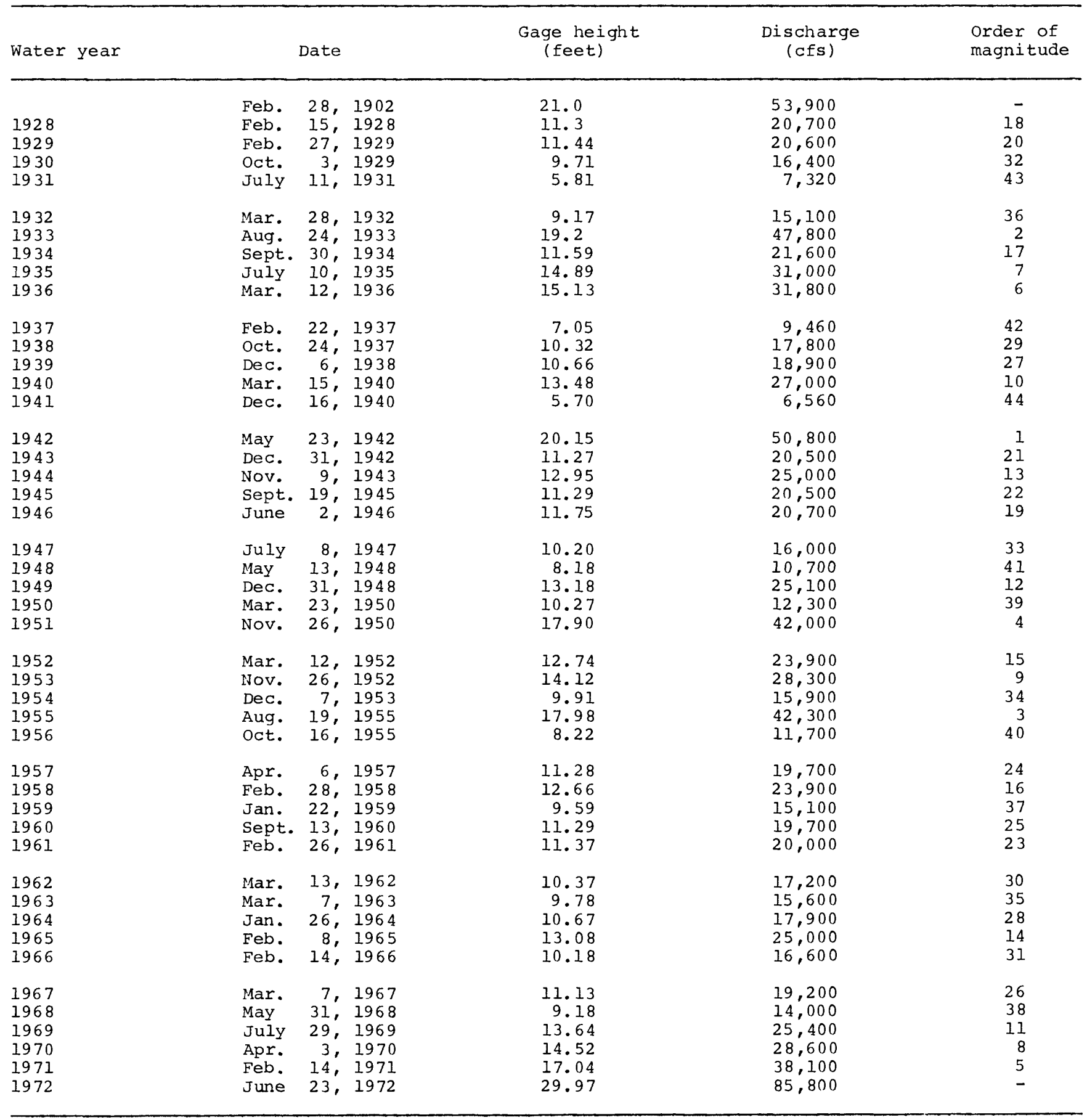




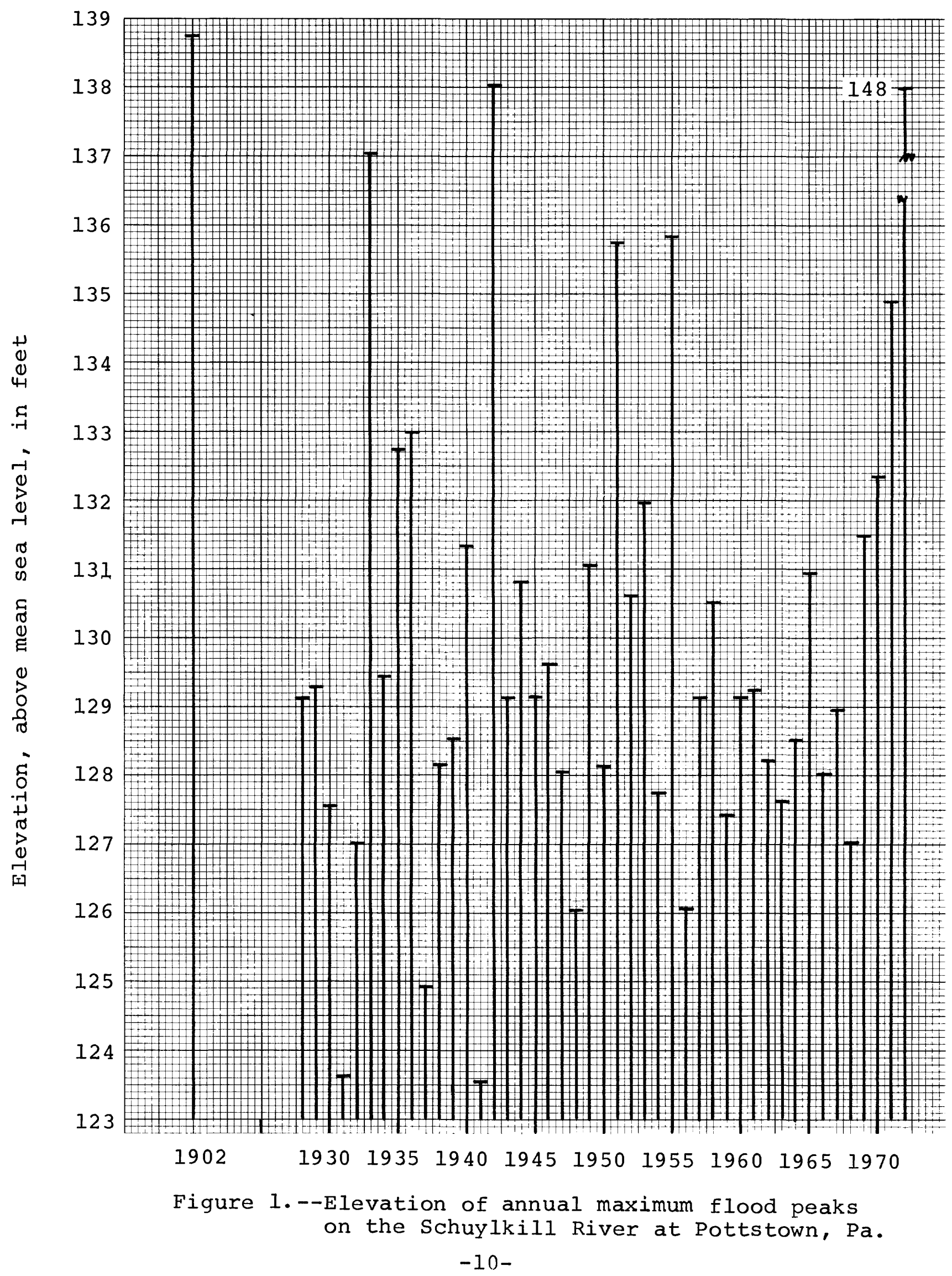




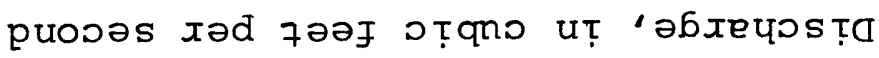
$\begin{array}{llllllll}\circ & 0 & 0 & 0 & 0 & 0 & 0 \\ 0 & \circ & 0 & \circ & \circ & 0 & 0 \\ 0 & 0 & 0 & 0 & 0 & 0 & 0 \\ 0 & 1 & 0 & \text { in } & 0 & \text { in } & 0 \\ 0 & 0 & \text { in } & \text { in }\end{array}$
$\begin{array}{ll}\circ & 0 \\ 0 & 0 \\ 0 & 0 \\ 0 & 0\end{array}$
웅

HHWH
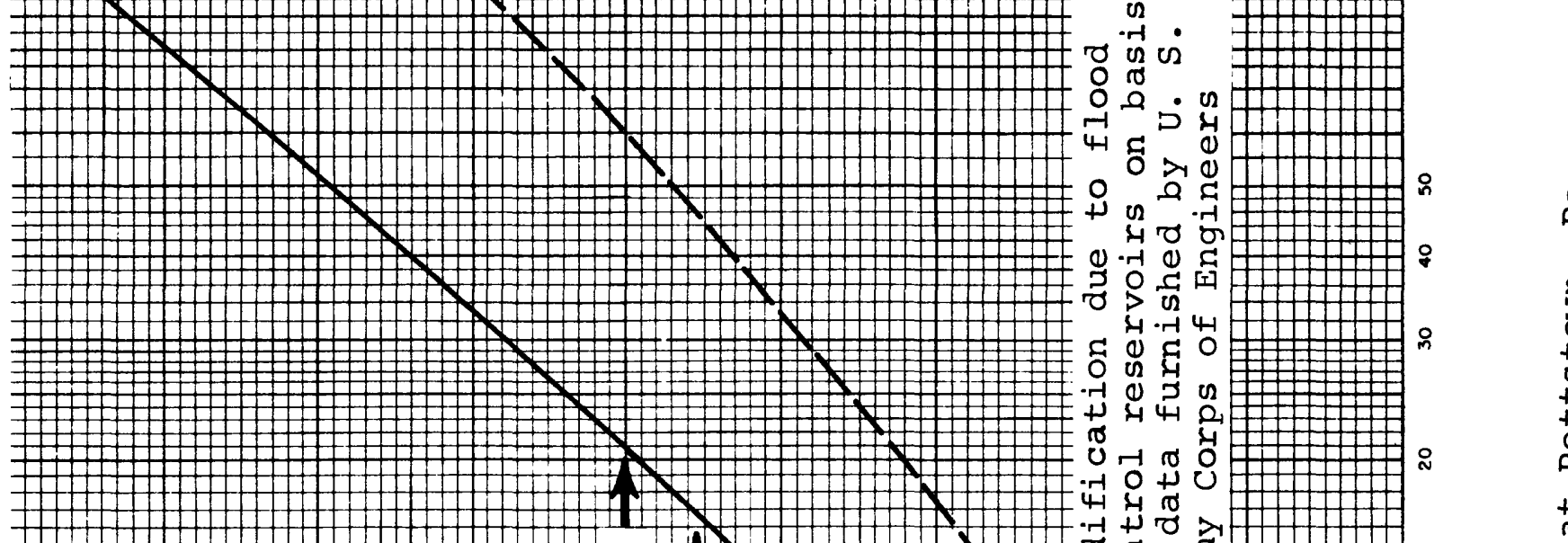

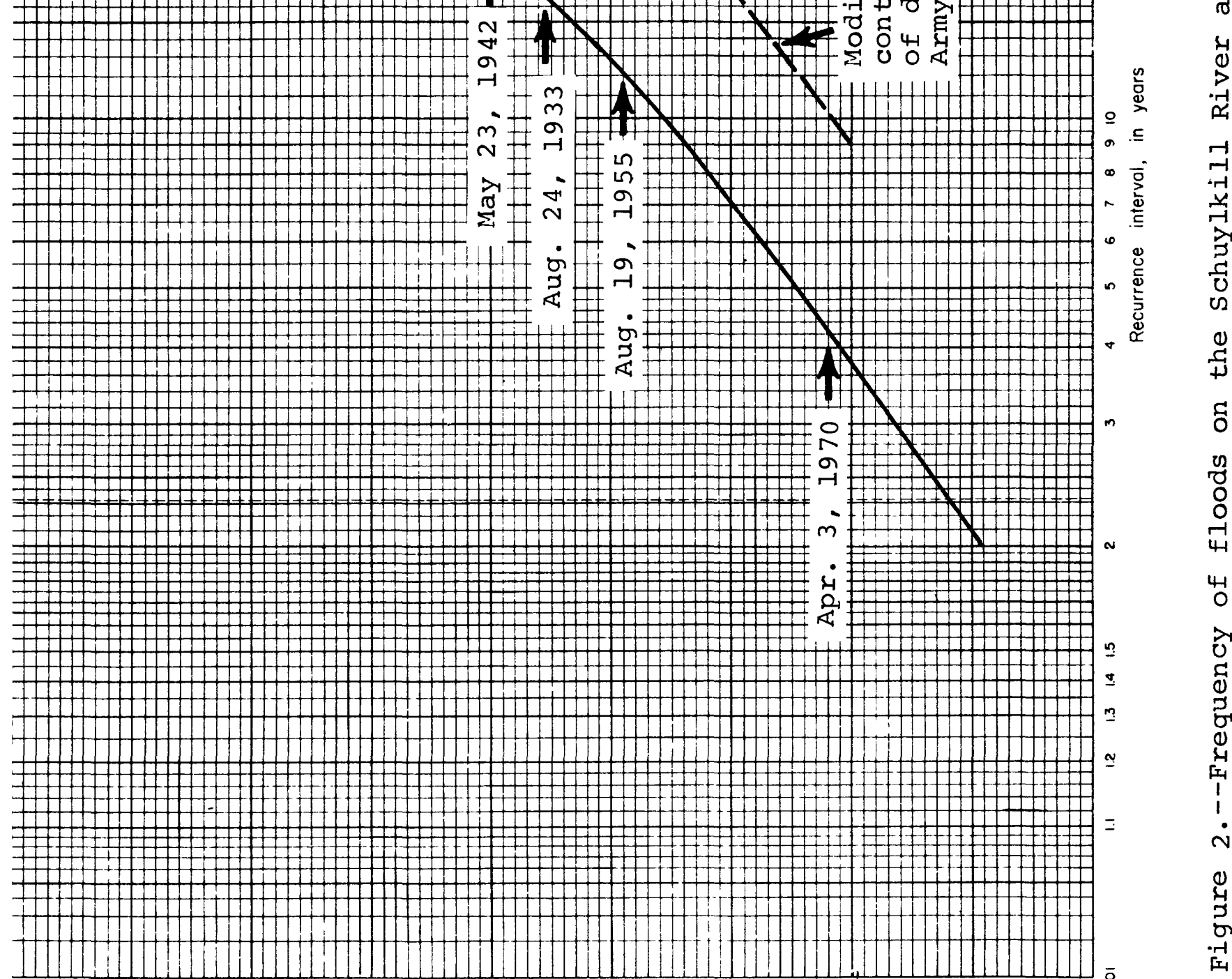

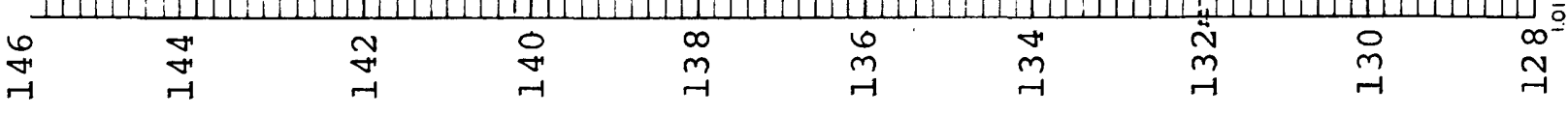

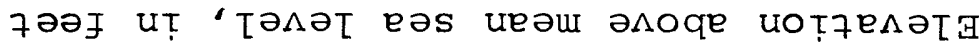


Plate 1 was compiled and enlarged to a scale of $1: 16,000$ from the following $71 / 2$-minute U.S.G.S. quadrangle sheets: Pottstown, Pa. (1968); Downingtown, Pa. (1968); Phoenixville, Pa. (1968); Malvern, Pa. (1968); Collegeville, Pa. (1966); and Valley Forge, Pa. (1952). The contour interval is 10 feet. River mileage above the mouth has been indicated on the map. The area inundated by the flood of May 1942, which was equivalent to a 50-year-recurrence-interval flood, has been delineated. There was not sufficient spread between this and the lesser flood of September 1955 to show a separate delineation. .

\section{Field Investigation}

Many high-water marks were found during field investigations in the summer of 1970 and spring of 1971. The high water of Mar. 14, 1971, which was the fifth highest peak during the period of record (October 1928 to September 1971) left enough marks to define a good profile. In March and April of 1971, the survey party ran seven cross sections and tied these sections and the high-water marks to mean sea level. The vertical control was maintained by levels tied to the bench marks listed in table 3 . 
Railroad from the station at Perkiomen Junction, $0.15 \mathrm{mi}$

northeast of the Perkiomen Junction Switch Tower, three poles south of fractional milepost $25 / 10,59 \mathrm{ft}$ southeast of the southeast rail of the southeast set of main line tracks, 67 ft northeast of the southeast end of a signal gantry, $8 \mathrm{ft}$ east of the east rail of a branch line leading to Altoona, $25 \mathrm{ft}$ west of the center line of a road that parallels the track, $0.8 \mathrm{ft}$ west of a metal witness post, about half a foot below the level of the track, and set in the top of a concrete post projecting 4 in.

USC\&GS B.M., $0.1 \mathrm{mi}$ north along the Reading Company Railroad from the station at Phoenixville, one pole north of fractional milepost $27 / 40,9.5 \mathrm{ft}$ west of the west rail of the west set of tracks, set in the top of the west end of the south concrete abutment of a bridge over French creek, about $1 \mathrm{ft}$ below the level of the track.

Standard USED bronze disk stamped 30-19.36; in right abutment of Black Rock Dam; a cross on south edge of abutment is 7.2 ft southeast of disk, a cross on southwest corner of abutment is $5.7 \mathrm{ft}$ southwest of disk; and a cross on northeast corner of abutment is $10.0 \mathrm{ft}$ northeast of disk.

Standard USED bronze disk stamped 40-1936; set in the left, upstream shoreward corner of left abutment of vincent Dam on Schuylkill River at Linfield.

Standard tablet stamped "117 Harrisburg 1903"; Spring City, $1.0 \mathrm{mi}$ west of; $480 \mathrm{ft}$ west of Pennsylvania Railroad bridge over canal; in southeast bridge seat of undergrade wagon bridge.

USC\&GS B.M., $1.1 \mathrm{mi}$ northwest along the Reading Company Railroad from the station at Phoenixville, $70 \mathrm{ft}$ southeast of the southeast abutment of the bridge over the Schuylkill River, $7 \mathrm{ft}$ southwest of the southwest rail, set in the top of bedrock, $33 \mathrm{ft}$ east of fractional milepost $28 / 40,27 \mathrm{ft}$ northwest of the northwest end of the Black Rock Tunnel, $2.5 \mathrm{ft}$ west of the southwest end of an 8-in. metal drainage pipe under the track, and about $1 \mathrm{ft}$ below the level of the track.

USC\&GS B.M., $1.2 \mathrm{mi}$ southeast along the Reading Company Railroad from the station at Phoenixville, or $1.75 \mathrm{mi}$ northwest along the Reading Company Railroad from the station at Perkiomen, two and one-half poles west of fractional milepost $26 / 20,4.4 \mathrm{ft}$ north of the north rail of the north set of main line tracks, set in the top of the north end of the more westward of two center piers of the bridge over Pickering Creek, about half a foot below the level of the track.

USC\&GS B.M., $3.3 \mathrm{mi}$ east along the Reading Company Railroad from the station at pottstown, $0.15 \mathrm{mi}$ southeast of an underpass of a road, two poles northeast of fractional milepost $37 / 10,23 \mathrm{ft}$ southeast of the southeast rail of the southeast set of tracks, $84 \mathrm{ft}$ east and across the tracks from a railroad telephone and signal box, $0.7 \mathrm{ft}$ west of a metal witness post, about $1.5 \mathrm{ft}$ below the level of the track, and set in the top of a concrete post projecting $4 \mathrm{in}$.

USC\&GS B.M., established by Philadelphia and Reading Railway at Linfield on the main line of the Philadelphia and Reading Railway, $285 \mathrm{ft}$ west of the abandoned passenger station, $255 \mathrm{ft}$ west of Township Road No. $443,45 \mathrm{ft}$ east of semiphore 136, $8 \mathrm{ft}$ north of the north rail of the northern most siding, set in the top of a concrete post flush with the ground. Reset in 1967.

USC\&GS B.M. at Royersford on the Reading Company Railroad, $331 \mathrm{ft}$ south of the south end of the station, $8 \mathrm{ft}$ north of the first pole south of fractional milepost $31 / 40$, $29 \mathrm{ft}$ west of the west rail of the west set of main line tracks, $9.6 \mathrm{ft}$ west of the west rail of a sidetrack, $200 \mathrm{ft}$ south of the center of a crossing of the railroad and Main Street, $0.7 \mathrm{ft}$ south of a metal witness post, about level with the track and set in the top of a concrete post projecting 1 in. 


\section{Magnitude and Frequency of Floods}

Stream-gaging station 01472000 at Pottstown furnished a reliable streamflow record. A stage-discharge frequency curve was developed from this record using the annual maximum peaks and a log-Pearson III analysis. Fairly stable channel-control conditions exist for high flows; therefore, the stage-frequency relation is applicable at the present time.

The magnitude of the flood peak discharge has been assumed to be a constant through the length of the study reach.

Recurrence interval, as applied to floods is the average interval of time within which a given flood height will be equaled or exceeded once. It does not imply periodicity. The recurrence interval is inversely related to the chance of a specific flood discharge being equaled or exceeded in any one year. Thus, the 25-year flood peak has a 4 percent ( 1 in 25) chance of being equaled or exceeded in any one year. At Pottstown, for example, a flood that reaches an elevation of $142 \mathrm{ft}$ above sea level is said to have a 50-year recurrence interval (fig. 2). A $142 \mathrm{ft}$ flood stage could be equaled or exceeded several times in a short period of time, but the interval between the occurrence of a flood of this magnitude or greater will average 50 years over a long period of time 
The general relationship between recurrence interval and flood elevation, as recorded on the Schuylkill River gaging station at Pottstown, is tabulated below:

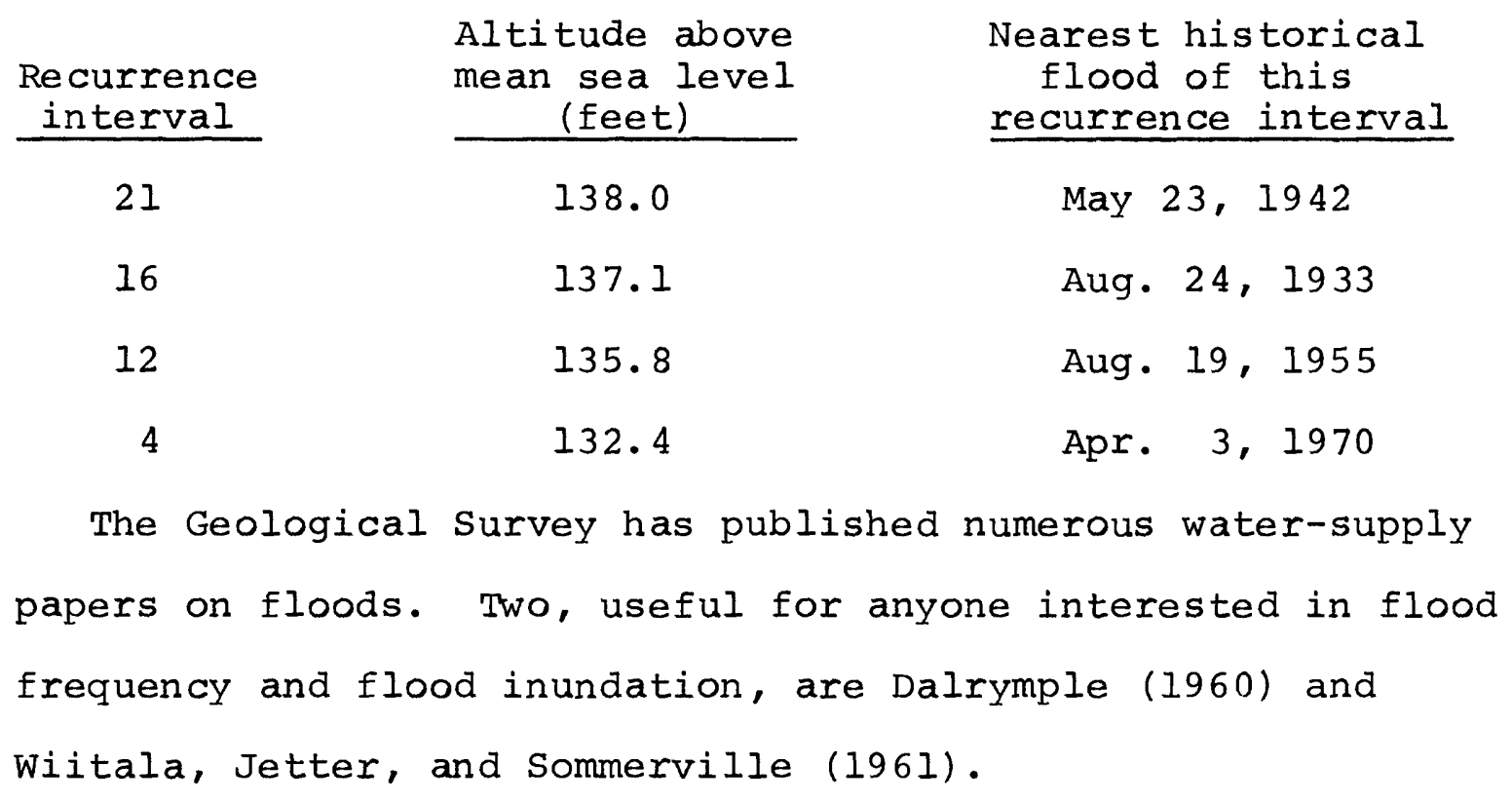




\section{Modification of Flood Elevations due to Major}

\section{Flood-Control Structures}

No major flood-control structures have been built in the Schuylkill River basin, although several are contemplated. The major water-control projects contemplated are the Maiden Creek Reservoir on Maiden Creek and the Blue Marsh Reservoir on Tulpehocken Creek. Both these reservoirs will be multipurpose - used for water supply, recreation, and flood control. The flood-control storage capacities will be 38,000 acre-feet in the Maiden Creek Reservoir and 32,400 acre-feet in the Blue Marsh Reservoir.

In this study modifications due to the Blue Marsh and Maiden Creek Reservoirs have been applied to the frequency studies on the Schuylkill River at Pottstown. The resulting modifications show a reduction in flood peaks of from approximately 5.0 feet at recurrence intervals of 100 years to 2.9 feet at recurrence intervals of 10 years and little or no reduction for the mean annual flood. This modified floodfrequency curve for the Schuylkill River at Pottstown shown in figure 2 was based on data furnished by the U. S. Army Corps of Engineers. 


\section{Flood Profiles}

The profiles of floods along the Schuylkill River (fig. 3) have been plotted from data on high-water marks shown in Table 1 provided by local residents, personnel of industrial plants in the study reach, and government agencies. Most of the floodmarks found were for the floods of Aug. 24, 1933, May 23, 1942, and Aug. 19, 1955. High-water marks for the Feb. 14, 1971 flood and the flood of record June 23, 1972, were also documented (table 1) and plotted on figure 3. Water-surface elevations obtained Dec. 6, 1971 during low-flow conditions have been plotted on the same sheet for comparative purposes. All elevations have been tied to mean sea level, datum of 1929 . 


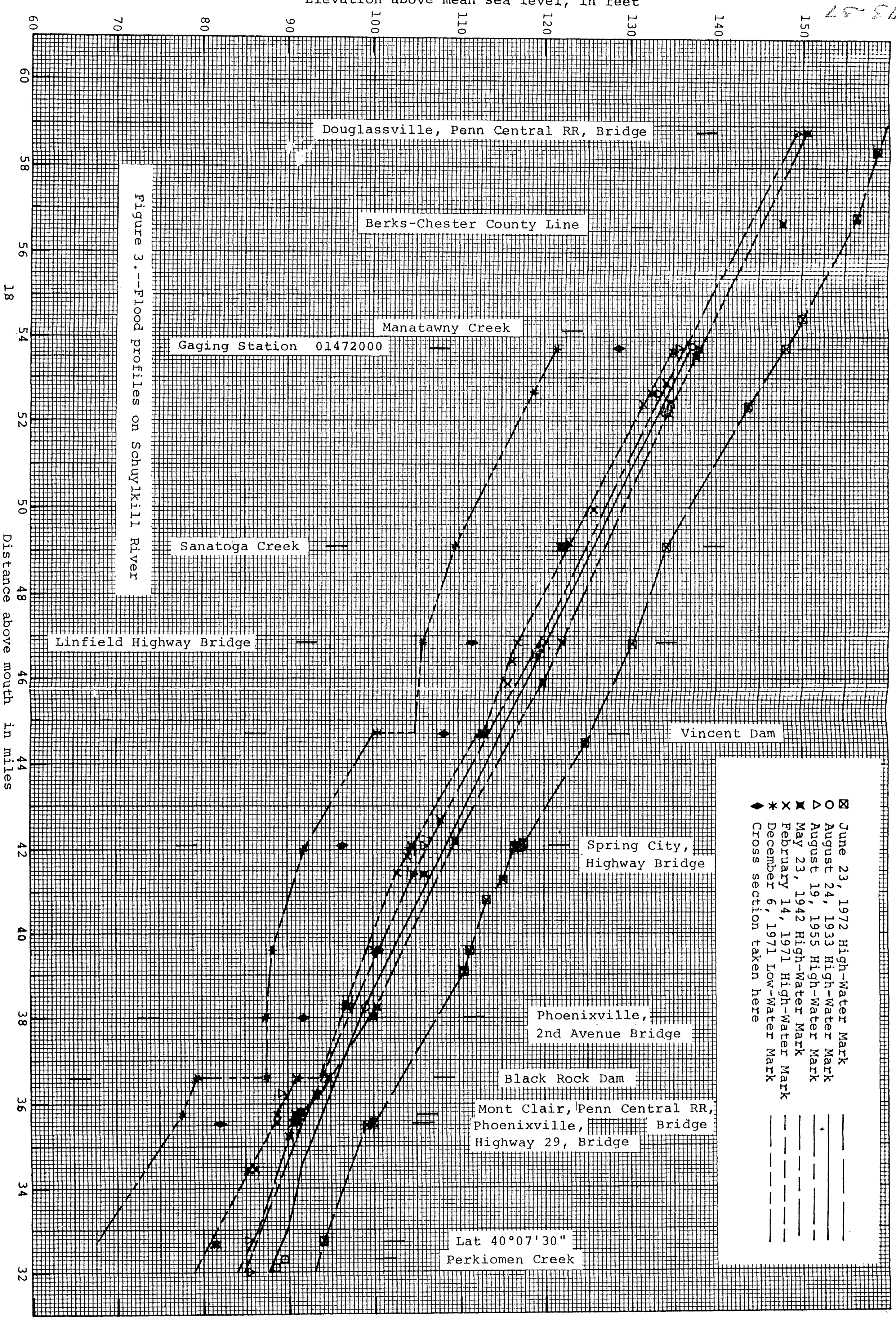




\section{USE OF FREQUENCY AND PROFILE RELATIONS}

This report can be used to identify areas that would be inundated by a flood of specific frequency and to compute the depth of flooding. 
Areal Extent of Flooding

The area inundated by the flood of May 23, 1942 is shown on plate 1 (in pocket). Inundated areas shown on tributaries are those that would be flooded by backwater from the Schuylkill River only. Heavy local runoff has caused more severe flooding on tributaries than that shown.

The areal extent of flooding at any specific location in the study reach along the Schuylkill River for a flood of a selected frequency can be determined in the following manner:

1. Determine the elevation of the flood having the desired frequency by using the Pottstown flood-frequency curve (fig. 2) .

2. Determine the relative position of the selected flood with respect to known floods at Pottstown, which are plotted on figure 2. For example, a 20-year flood would have an elevation of 137.8 feet on the Pottstown frequency curve. The 21-year flood has an elevation of 138.0 feet and the 12-year flood has an elevation of 135.8 feet.

Then $\frac{138.0}{2.2}$ and $\frac{137.8}{2.0}$. Therefore, our 40-year flood should plot $10 / 11$ of the distance up from the 12-year flood of Aug. 19, 1955 to the 21-year flood of May 23, 1942 at the Pottstown gaging station and at any other selected location on the profile (fig. 3). 
3. Determine the river mileage for a specific location from the map (plate l) and compute the flood elevation at that mileage using the technique described in step 2 and the profiles shown in figure 3 .

4. Locate the point on plate 1 at the specific location where the computer water-surface elevation intercepts the ground surface. For the most accurate results this delineation should be done by differential leveling to a specific location. If it is done on a topographic map the error may be plus or minus half the contour interval.

\section{Depth of Flooding}

The depth of flooding can be estimated by subtracting the ground elevation at any specific point from the water-surface elevation obtained from the profile in the manner described above.

\section{Cross Sections}

Figures 4 to 9 show typical cross sections in the study reach. These cross sections give a general idea of the depth of flooding. 


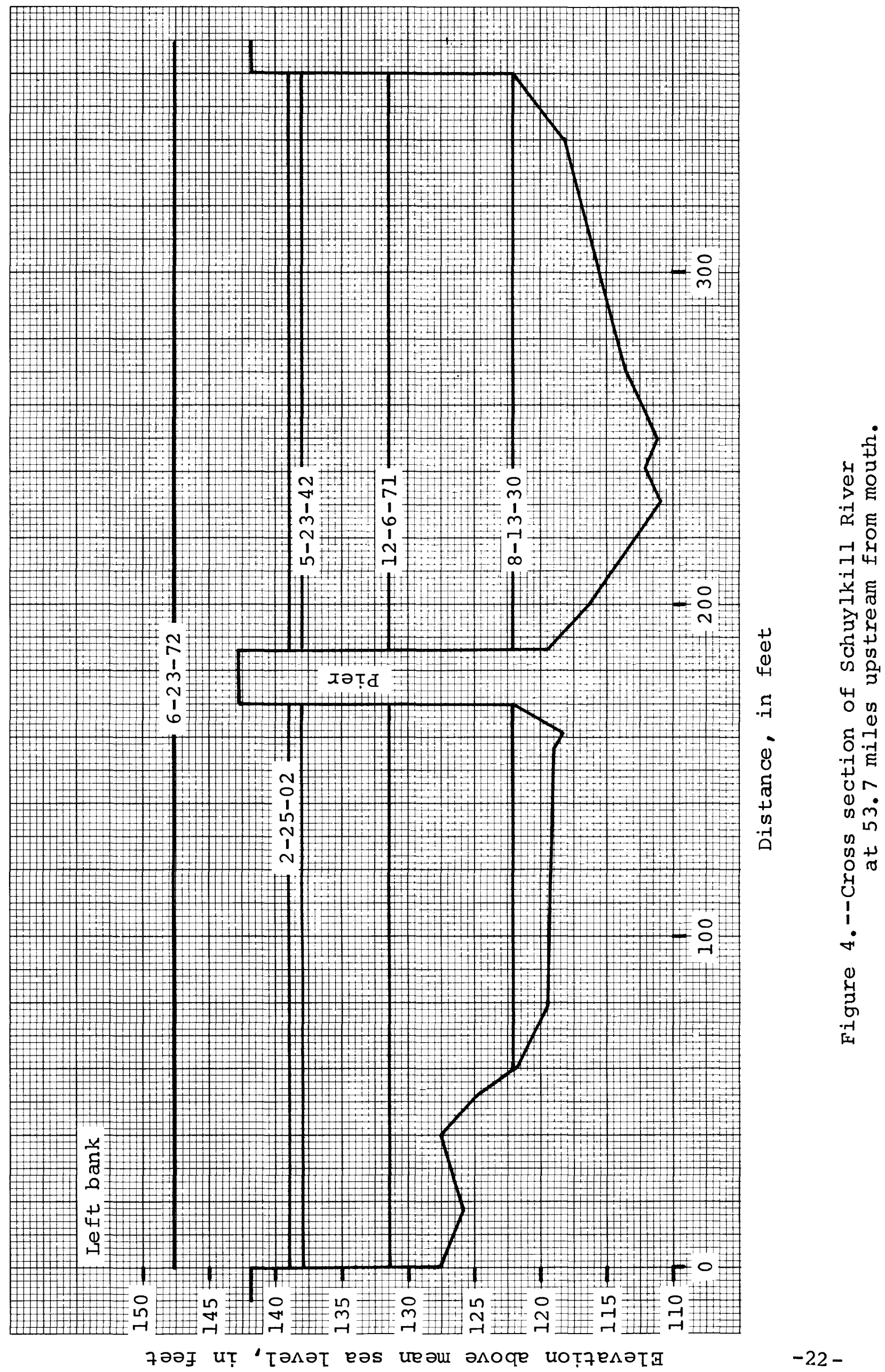




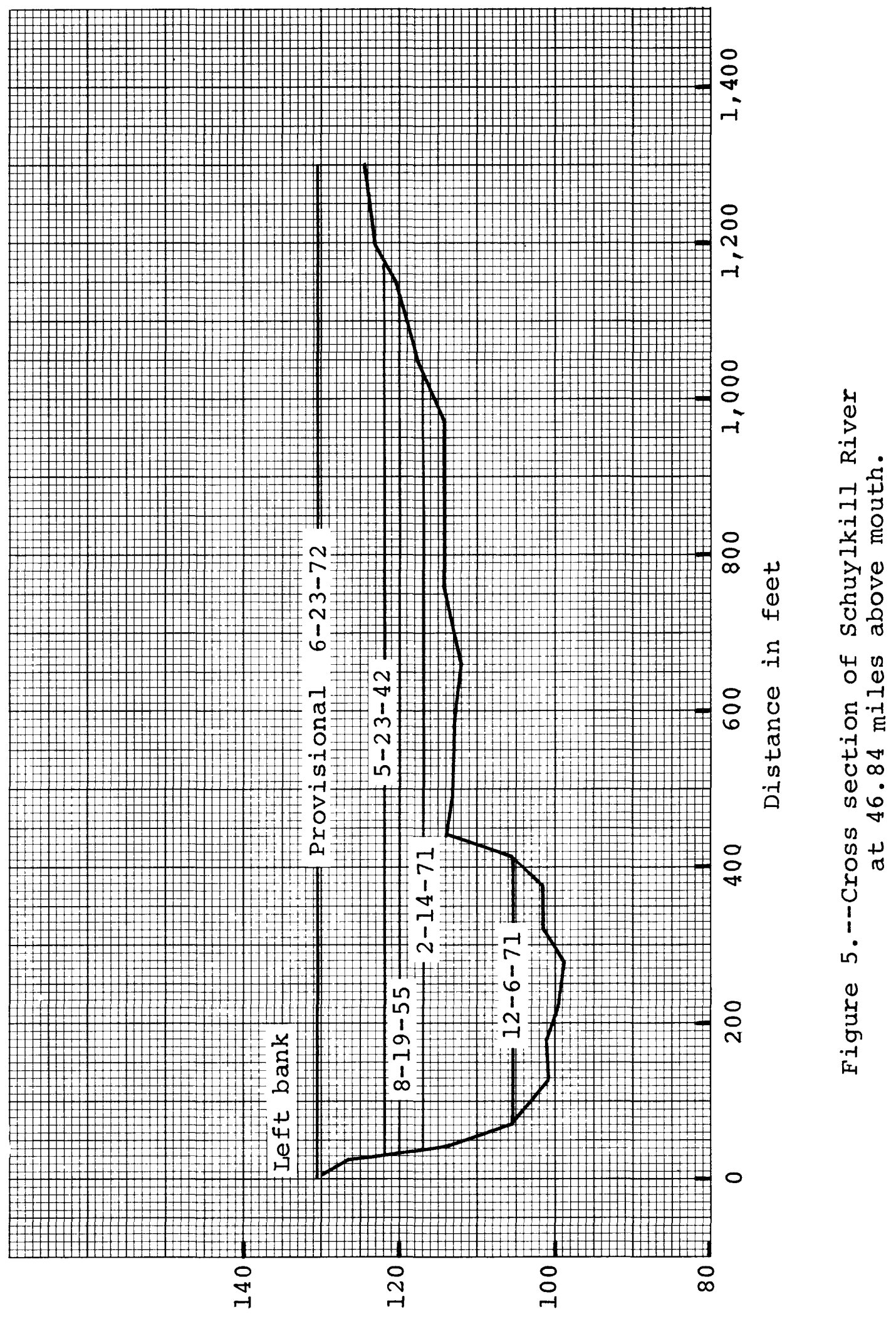

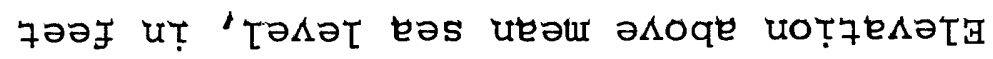




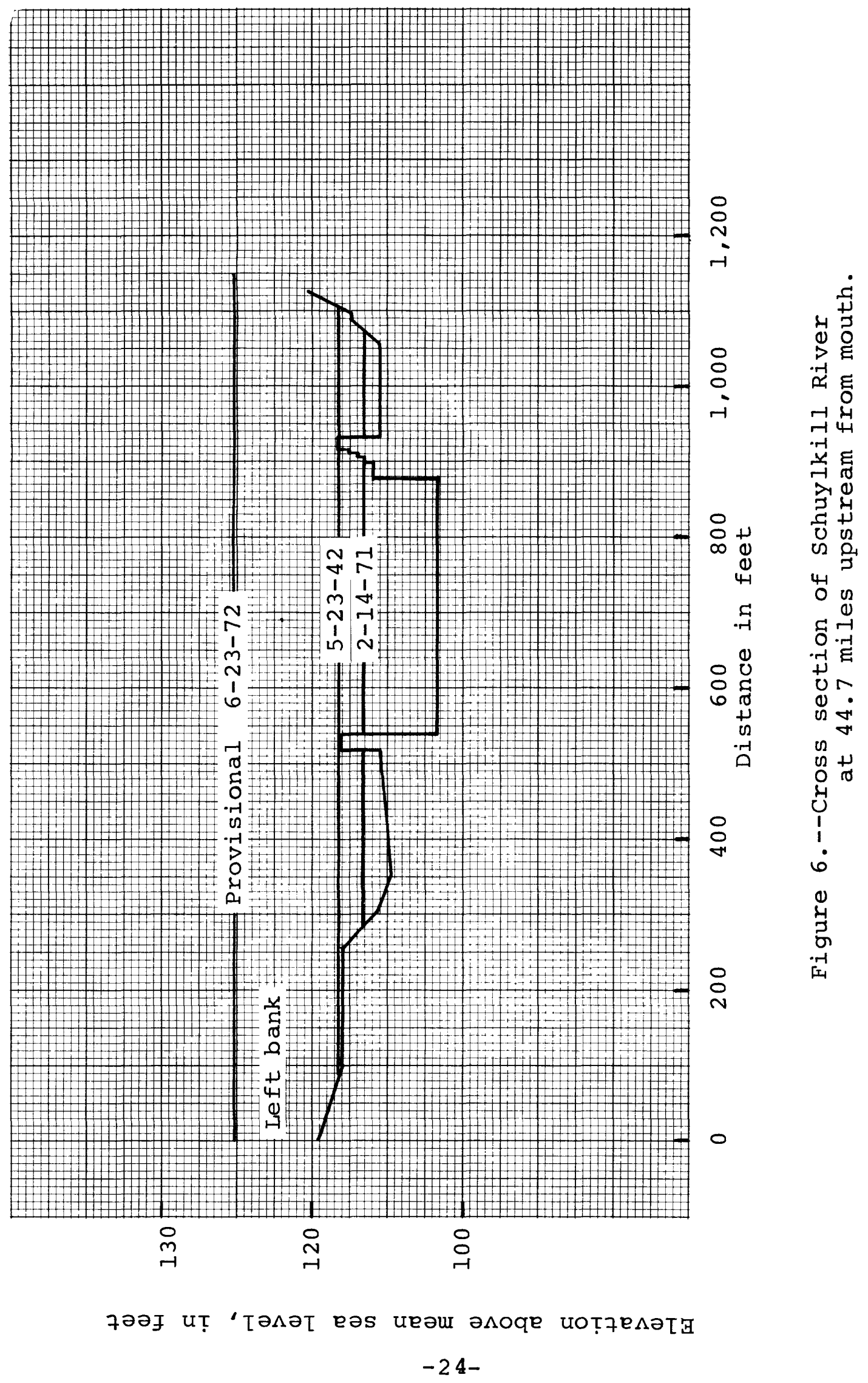




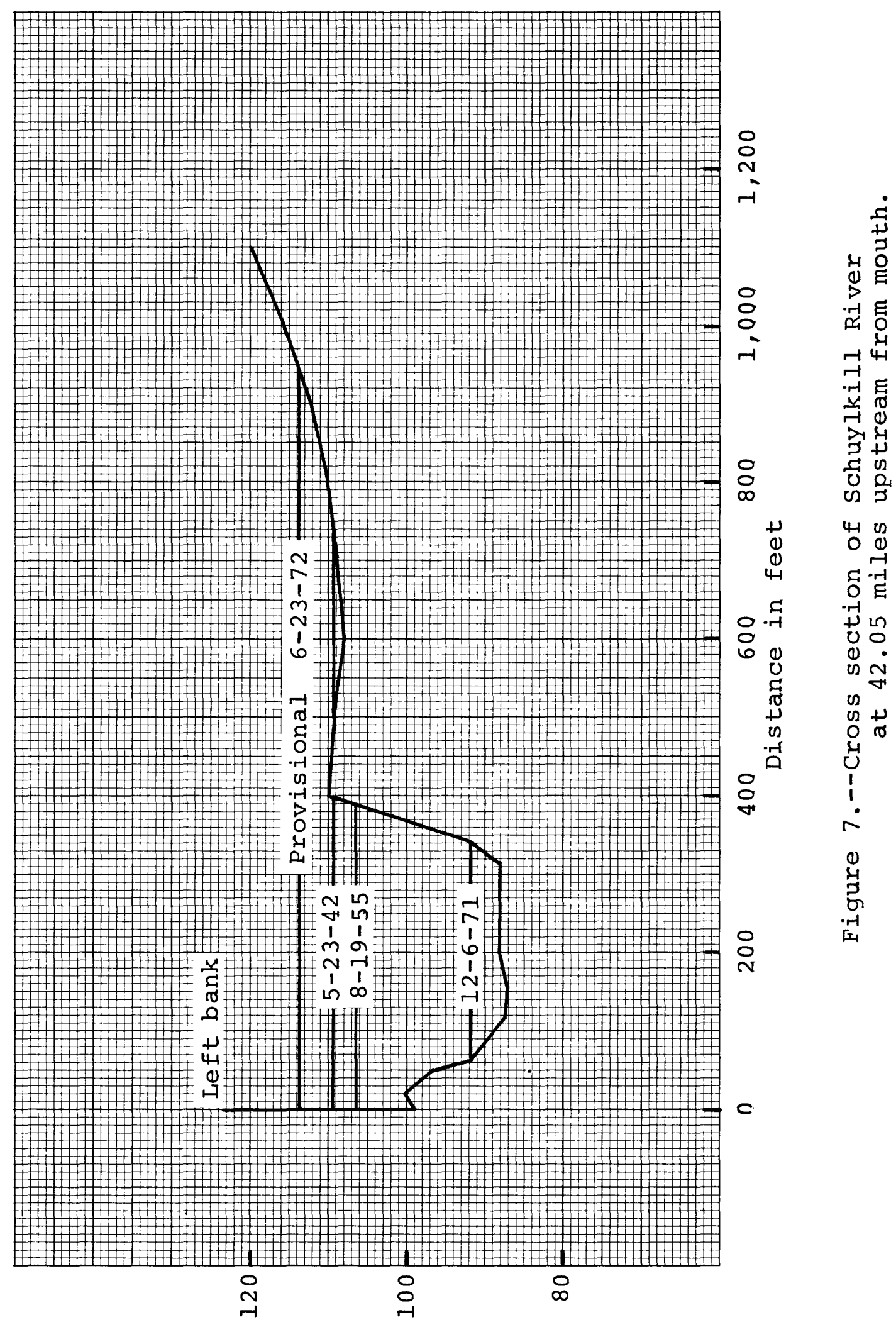

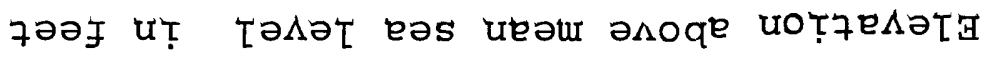




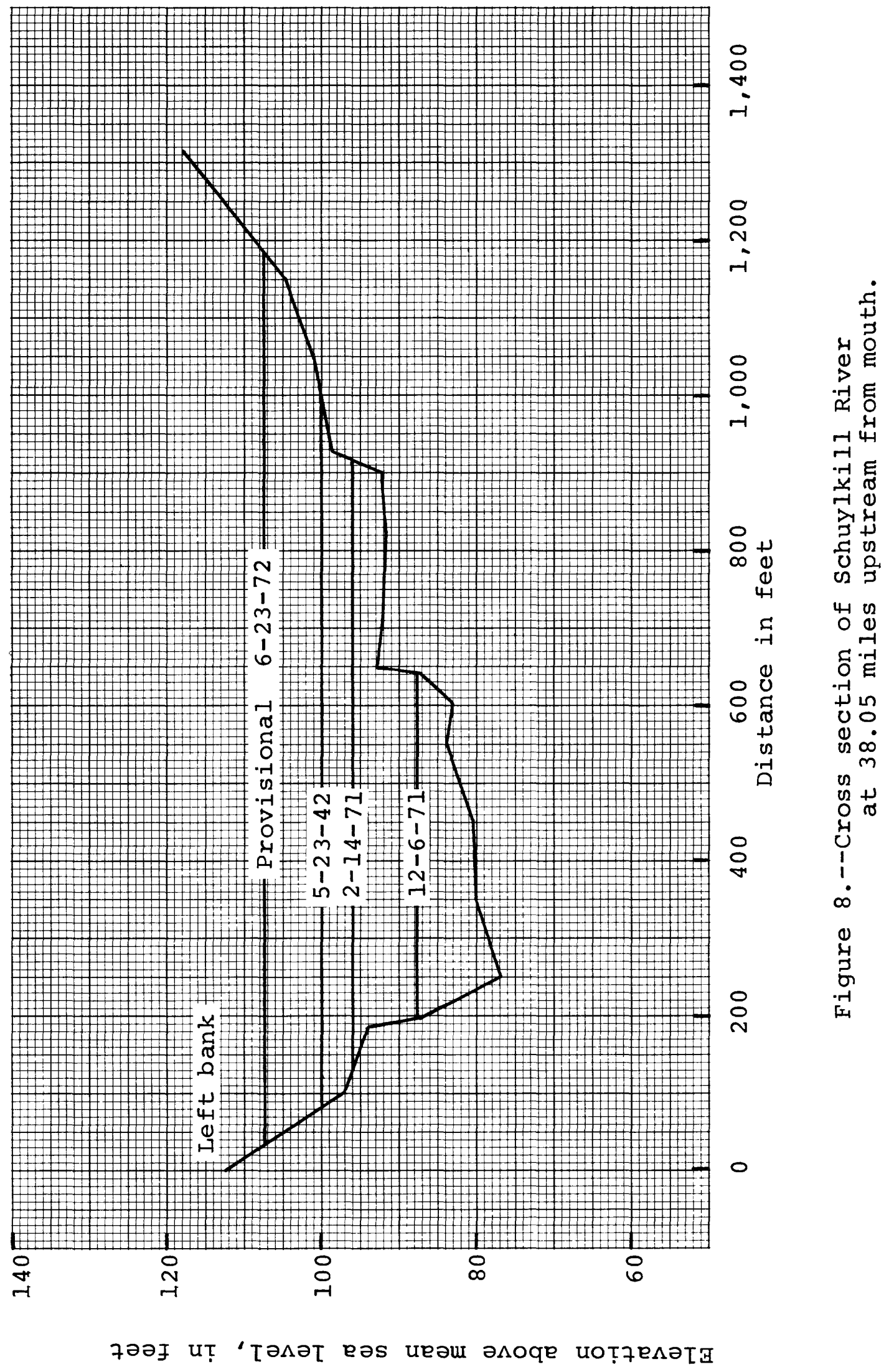




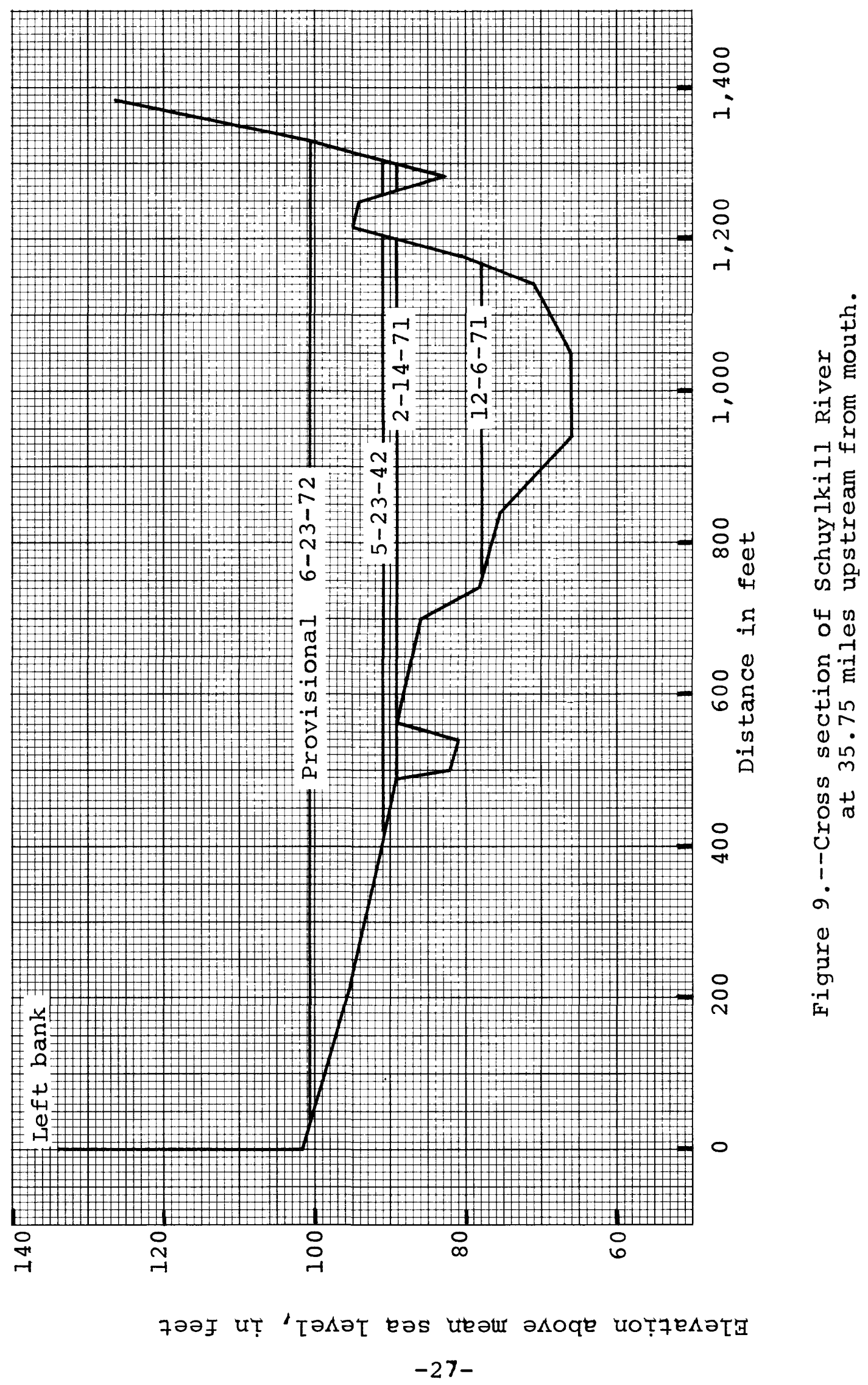


Streamflow data shown within this report are accurate within the limits of the methodology used. Flood records have been kept for only a relatively short time, and there is no assurance that meteorologic conditions will not change in the future. Modern man has made great changes in the topography and vegetation. These changes may have great effects on the runoff characteristics of a basin or the carrying capacity of a stream. With the passage of time, bank and channel conditions are often changed. New buildings and highways are constructed, encroachment and fills may limit the channel, streambeds scour or fill, new bridges may constrict the channel, or stream clearance may facilitate flow.

Extrapolating the flood-frequency curves beyond the limits shown is not advisable. 


\section{SELECTED BIBLIOGRAPHY}

American Society Civil Engineers, Task Force on Flood Plain Regulations, Flood Control Committee of the Hydraulics Division, 1962, Guide for the development of flood plain regulation, progress report: Am. Soc. Civil Engineers, Proc., v. 88, no. HY 5, p. 73-119.

Bogart, D. B., 1960 , Floods of August-October 1955, New England to North Carolina: U.S. Geol. Survey Water-Supply Paper 1420 .

Bue, Conrad D., Flood Information for Flood-Plain Planning: U.S. Geol. Survey Circular 539.

Busch, W. F., and Shaw, I. C., 1960, Floods in Pennsylvania, frequency and magnitude: U.S. Geol. Survey open-file report.

Dalrymple, Tate, 1960, Flood-frequency analysis: U.S. Geol. Survey Water-Supply Paper 1543-A.

Dola, Steven, 1961, Flood damage alleviation in New Jersey: New Jersey Dept. Conserv. and Econ. Devel., Div. Water Policy and Supply, Water Resources Circ. 3, 20 p.

Goddard, J. E., 1963, Flood plain management improves man's environment: Am. Soc. Civil Engineers, Proc., v. 89 , no. WW 4 , p. 67-84.

Mangan, J. W., 1942, The floods of May 1942 in the Delaware and Lackawanna River basins: Pennsylvania Dept. Forests and Waters.

Molloy, J. J., 1960, Flood discharge records relation to Pennsylvania streams: Pennsylvania Dept. Forests and Waters.

Tice, R. H., 1958, Delaware River basin flood frequency: U.S. Geol. Survey open-file report.

White, G. F., 1961, Strategic aspects of urban flood plain occupance: Am. Soc., Civil Engineers Trans., v. 126 , pt. 1 , p. $63-75$.

Wiitala, S. W. , Jetter, K. R., and Sommerville, A. J., 1961, Hydraulic and hydrologic aspects of flood-plain planning: U.S. Geol. Survey Water-Supply Paper 1526. 